\title{
An Assessment of Problems of Primary School Children with Disabilities in Uganda
}

\author{
Dastan Bamwesigye*, Petra Hlavackova \\ Department of Forest and Wood Products Economics and Policy, Faculty of Forestry and Wood Technology, \\ Mendel University, Czech Republic
}

Copyright $(2018$ by authors, all rights reserved. Authors agree that this article remains permanently open access under the terms of the Creative Commons Attribution License 4.0 International License

\begin{abstract}
This research study focused on an investigation into the factors contributing to the dropout of children with disabilities (CWD) in rural schools in Uganda with a case study of Ntungamo District. Questionnaires interviews were carried out by the research team. The data collected was compiled and analyzed. Findings indicated that majority of the respondents were in agreement that social and economic needs of children with disabilities is the major factor that contributes to the drop out of children with disabilities from rural schools. Other outcomes show that shortage of staff in schools contributes to drop out of children with disabilities, poor teachers attitudes towards the disabled children, poor government policies, hatred and discrimination against the disabled children, absence of morale by teacher's, lack of special equipment for teaching children with special needs was also averagely supported. The study recommends that the Government of Uganda and the responsible ministry put aspects of inclusion of all children into consideration, and also provide the necessary financial support as well as intensifying long life learning programs for special needs teachers with focus on primary education among other levels. Further comprehensive research ought to be of paramount importance in understanding challenges facing CWD.
\end{abstract}

Keywords Disability, Special Needs Education, Policies, Support, Drop-out, Teachers' Attitudes

\section{Introduction}

The government of the Republic of Uganda came up with the policy of providing education for all at the primary level in rural areas. Before the initiation of UPE in 1997 , only $1 \%$ of Ugandans had access to schools Ainscow [5], Grogan [12]

Primary education in Uganda is largely characterized by The Universal Primary Education (UPE) programme which had started by 1997. It resulted in an increase in primary school enrollment in Uganda Ainscow [5], Deininger [10], Grogan [12], Jackson et al. [18], Nishimura, Yamano, \& Sasaoka [25].

With the introduction of UPE, the government of the Republic of Uganda considered disabled children by having them first enrolled out of the four children per family and then a girl child per the provisions of the programme.

Even though there is almost equal access at lower primary levels between the disabled and the non-disabled children in the East African state due to UPE policy, there are still numerous other challenges facing the sub-sector such as inequalities at the upper rural primary school levels for some reasons, especially among children with disabilities. Despite the government of Uganda's interventions, numerous school going children with disabilities in Ntungamo district still drop out of primary schools, especially in rural areas.

While a number of ministries in Africa are involved with issues related to disability, there is not yet a coordinating body across these ministries that would mobilize national parent, education, health, rehabilitation, construction and other supports for the Inclusive Education effort Jackson [17].

Like most other countries, the attitudes about disability in Uganda range from enlightened to backward, by which children may be kept from school, because of feelings of shame among family members. The government of the Republic of Uganda came up with the idea to institute an educational Review Commission with the intention of reforming the educational system which had left persons with disabilities in the hands of private organizations. The commission came up with an important recommendation which was focused on making education systems more inclusive. All units and annexes for special education attached to normal schools and colleges should be taken over by the Ministry of Education and Sports and to be integrated into schools and colleges, while adequate provision of supports should be made for teaching 
disabled students, taking note of children who drop out of school due to various factors, which should be investigated.

The process of implementation of the rural programme is faced with a variety of loopholes, and due to that, many children with disabilities drop out of schools under rural programme due to environmental and social factors. However, the school drop out rate and the factors that contribute to the school drop out of the disabled children, especially the girl-child, remains largely unpublished Ainscow [5].

Although there are not many published works available on the factors that seem to be affecting education of the disabled children in rural areas, school drop out factors appear to be related to the distance the child walks to get to school, harassment at school by other children due to physical insecurity and lack of special scholastic materials. This research therefore, sets out to investigate causes of school dropouts of disabled children in the District of Ntungamo in Uganda.

\section{Statement of the Problem.}

The UPE programme initiated in 1997 resulted in a 70\% increase in primary school enrollment in Uganda. Although there is almost equal access at lower primary levels between disabled and non-disabled children because of UPE policy, across the gender, there are still inequalities at the upper rural primary school levels for some reasons, especially among children with disabilities. Despite the government interventions, many children with disabilities in Uganda, and Ntungamo district in particular continue to drop out of primary schools, especially in rural areas. Some of the factors that appear to be affecting the education of the disabled children are related to distance to school, harassment at school by other children due to physical insecurity and lack of special scholastic materials. The research, therefore, sets out to find out the causes of school dropouts for disabled children in Ntungamo district.

\section{Goal and Objectives of the Study}

The purpose of this study was to investigate the factors responsible for the drop out of children with disabilities from rural schools in Uganda. The objective was to find out factors that contribute to the dropping out of school children with disabilities from rural primary schools.

\section{Significance of the Study}

The study will contribute to board of knowledge about the factors contributing to primary school dropout, children with disabilities, and special needs education.

The findings of this research will provide a basis for appropriate advocacy for observation of the rights of the children with disabilities in the field of education.

The basis for carrying out further research that is to say based on the recommendations.

\section{Research Question}

What are the major factors contributing to the drop out of children with disabilities?

\section{Scope of the Study}

This study will be conducted in Ntungamo district. It will cover four universal primary education schools in Ntungamo district and homes for the parent of children with disabilities. In carrying out the study, the researcher will use the classroom teachers, children with disabilities and parents for children with disabilities as respondents mainly to investigate factors responsible for the drop out of children with special educational needs/ disabilities from rural schools in Ntungamo district, as well as finding the efforts put forward in order to make adjustments and transformations in the situation of children with disabilities (CWDs) at primary level of education.

\section{Related Literature}

WHO [33], defined disability as not a question of health problems but a complex phenomenon that reflects the collaboration between structures of a person's body and features of the environment in which they live. The report categorized the term disability into three major situations:

- impairments

- $\quad$ activity limitations, and

- $\quad$ participation restrictions

Impairments are problems in physical or structure, activity limitations are difficulty faced by individuals in executing tasks, whereas participation restriction are problems encountered by an individual in association with life circumstances (WHO [33]). The report suggested that PWDs experience a slighter margin of health, both because of poverty and social exclusion. Which makes secondary conditions such as pressure sores or urinary tract infections even worse. The report further observed that people with disabilities face barriers in accessing the services they need in many settings such as health and rehabilitation. Other services such as education lacked highly, while ranking met and unmet needs, education services in general and on average scored $23.3 \%$ and $49 \%$ for received and needed services respectively.

Labie et al [38] examined discrimination in Ugandan's institutions. Their results were shocking. Bank and other lending Loan officers are found to be more prejudiced against disabled borrowers than in other institutions' employees. Additionally, to make matters worse, even the International Momentary Fund (IMF) did not decrease or punish their funding to such discriminating lending institutions or officers.

Katsui and Kumpuvuori [36], asserted that Uganda was on the right truck for inclusion of people with disabilities (PWDs) in the political arena of the country. Their study 
found out that from the excutive to the local levels of governance, there is a representative of people with disabilities such as secretary for people with disabilities at Local council one (LC1). However, Hoogeveen [34], Lwanga-Ntale [35], noted that PWDs are mong the most miginalised groups of people in the ugandan society as well as the among the most cronically infested with poverty especially in the households where most members are disabled and un-able to function or perform income generating activities to feed or care the family members.

Barrett and Marshall [37] suggested the development of human capacity of people with disabilities (PWDs) through models such as degree courses focusing on disability and human development, cultural asspects relating to disabilty, accessibilty and innovation eduaction. They offered alternatives for communicating disabilty as a ray of hope and service delivery through constructive inclusion.

Fine, \& Asch [11], Oliver [27], define disability as a form of physical deformities such as scars, physical manifestations of anorexia nervosa, or of a physical disability or social disability, such as obesity and also mental illness. Children with such disabilities are always stigmatized and sometimes hated and thus leads to them dropping out of schools. The other nature of disability which leads to school dropout is the overt or external deformities such as leprosy, clubfoot, cleft lip or palate and muscular dystrophy. He further stresses that normally children with these kinds of disabilities are isolated and discriminated against, feel isolated, thus leading to their dropping out of schools (Abberley [1], Susman [30]).

According to Hegarty [14], there is a continuing problem as shortage of appropriate staff, which still makes it difficult and often impossible to provide adequate teaching. This means that the shortage of specialist teachers for children with disabilities (CWDs) makes them drop out of school. The presence of children with special needs inevitably affects the organization, and the running of any class and teachers need to have undergone such special training to meet these special needs.

Winzer [31] in the study carried out in Brazil on teaching children with disabilities/special needs shows that they fail and later quit school because of their socio-economic and cultural environmental needs. Financial and other resources, parents pay for their children's educational materials and many parents are unable to meet these requirements, which result in the children being deprived of their education they have a right to.

Hegarty [14], noted evidence from Scotland that majority of the primary teachers felt inadequately prepared for slow learners, led to children whose needs are not being met which led to dropping out of the school of most CWDs. Hegarty further notes that; where pupils with special needs are concerned, or even individuals, new or modified curriculum, equipment ranging from cassette recorders to adopted micro-computers, special transport arrangements, all this can add up to a very considerable expenditure.

Oliver [27] stated that: the education system has failed children with disabilities in that it has failed to equip children with disabilities with enough materials to exercise their rights as citizens or accept their responsibilities, thus forcing them to drop out of school.

Hegarty [14], conducted in Britain about the morale of teachers and their motivation. It showed that low morale of teaching force was a major threat facing the maintained education system. This he says was due to teachers' perception of their low status in the national labour market, which created poor conditions affecting whole school reforms.

Regarding to Winzer [31], study carried out in the United States of America into the attitudes of teachers where the legal requirement to educate pupils in the least restrictive environment which meant that teachers were faced with teaching pupils with special educational needs, indicate that teachers did not favor main streaming of children with special educational needs and other professionals were found to perceive these pupils in the negative light. Similar related studies made in Taiwan indicated that teachers' attitudes prevented integration of children with special needs into ordinary schools. The same study contends that regular teachers do not want disabled children staying in their classrooms.

Lander et al. [22] noted that the United States department of special education $(1998,1999,2000$, and 2001) and the professional literature indicate that there is a severe chronic shortage of special education teachers in the United States. 98\% of the nation's school districts report special education teacher.

Seidman and Anang [29], Seidman, \& Grier [28] and Ishumi [16] argue that the questions which echo the current concern worldwide, in the south and Africa, in particular, is that, a tiny majority of children with special needs receive formalized education and that there is a decline in access and quality of education despite the initial post-independence expansion.

Allinder [6], Avramidis \& Norwich [7], Mudra, et al. [24] noted that special education provision is viewed as any form of additional assistance or help which is provided from birth to maturity in order to overcome educational difficulties. He further goes ahead and asserts that it is a common practice for countries south of Sahara to copy the pattern of education followed in developed countries mainly the USA and UK. Unfortunately, however, countries in the south of Sahara lack the necessary qualified personnel and equipment needed as well as the spare parts and technicians to service and repair the equipment.

\section{Methodology}

Rendering to Creswell [9], Hall [13], methodology is defined as an overall approach to studying the research 
topic and the constraints, dilemmas and ethical choices involved. This chapter looks at the discussion of the information concerning the research design, target population, sample and sampling procedure and method of data collection which were used while conducting the study.

\section{Research Design}

The researcher used qualitative and quantitative approaches in the study, and this is because they both provide an in-depth account of data about a particular instance that the research investigates. It provides all the necessary information regarding an in-depth account of the factors responsible for the drop out of CWDs from rural schools.

Target Population and Sample and Sampling Procedure

According to Koul [21], population refers to any collection of specified group of human beings or of non-human entities such as objects, educational institutions time units and geographical areas. In this study, the target population was children with disabilities, classroom teachers and parents for children with disabilities/special needs education.

Koul [21] defines sampling as process through which a relatively small number of individuals or measures of individuals or objects or events was selected and analyzed in order to find out something about the entire population from which it is selected.

The researcher took a sample of;

- 4 children with disabilities,

- 4 parents for children with disabilities and

- 4 teachers of children with disabilities,

- 1 District Education Officer (D.E.O),

- 1 district inspector of schools,

- 10 opinion leaders and

- 20 elders all totaling up to 44 respondents.

The procedure for selecting children with disabilities was purposively done. Two of the respondents were pupils, and two had dropped out of school. This is because the respondents were expected to give the required information based on their real experience. The disabled children are selected because they do understand their issues more than other persons.

According to Hall [13], a method refers to a particular research technique which has been employed, adapted and succeeded in reporting about a particular instance. In this study, the researcher used interview as the main method of data collection.

This is a method of data collection which involves a researcher asking questions and receiving responses from the person being interviewed. They are commonly one on one, face to face but can also be conducted in groups. They offer the possibility of modifying one's line of inquiry. There is a possibility of following up interesting responses and digging deeper into them, and this makes the study more relevant and meaningful.

Data Processing and Analysis

Upon gathering the data, analysis was done using 5point Likert scales of agreement and disagreement. Percentage and frequency tables were used to describe the result. Thereafter the data were edited, coded, and analyzed to ensure consistency and completeness. Questionnaires were issued to participants to fill by the researcher. The data was analyzed, compiled and interpreted for final report writing. Qualitative and quantitative description of data was used to list responses and opinions from questionnaires (Maxwell [23], Creswell [9], and Punch [20]). Analysis and interpretation was based on the responses and opinions, beliefs and attitudes expressed by participants. These were summed up and presented in frequency tables and percentages.

\section{Study Limitations}

The study suffered limited literature on school dropout of children with disabilities in Uganda. Also, the study design did not include many CWD which makes the sample size very small to generalize. This also goes for the families of CWD.

The study also was limited by funding which compromised the sample size for data collection.

\section{Findings}

The objective of the study was to find out factors that contribute to the dropping out of children with disabilities from rural schools in Uganda and it was attained as follows;

Findings from table 1 indicates that 13 (29\%) of respondents were in strong agreement that social and economic needs within children with disabilities were the major factor which contributes to drop out of children with disabilities from rural schools, 14 (32\%) agreed, whereas 7 (16\%) strongly disagreed. Further still, 5 (11\%) disagreed and another $5(11 \%)$ were not sure that such needs among children with disabilities cause dropping out of school. This response is an indication that social and economic needs could lead to the dropping out of children with disabilities from rural schools because they also have the same needs as the able-bodied ones. 
Table 1. Showing factors that contribute to dropping out of children with disabilities from rural schools

\begin{tabular}{|c|c|c|c|c|c|c|c|c|c|c|}
\hline \multirow{2}{*}{ RESPONSE } & \multirow{2}{*}{\multicolumn{2}{|c|}{$\begin{array}{l}\text { Strongly } \\
\text { Agree }\end{array}$}} & \multicolumn{2}{|c|}{ Agree } & \multicolumn{2}{|c|}{ Disagree } & \multicolumn{2}{|c|}{$\begin{array}{l}\text { Strongly } \\
\text { Disagree }\end{array}$} & \multicolumn{2}{|c|}{ Neutral } \\
\hline & & & & & $\mathbf{F}$ & $\%$ & & & $\mathbf{F}$ & $\%$ \\
\hline $\begin{array}{l}\text { Presence of social and economic needs within children with } \\
\text { disabilities }\end{array}$ & 13 & 29 & 14 & 32 & 5 & 11 & 7 & 16 & 5 & 11 \\
\hline There is shortage of staff in schools & 10 & 23 & 20 & 45 & 10 & 23 & - & - & 4 & 9 \\
\hline The few teachers available don't like teaching the disabled children & 8 & 18 & 15 & 34 & 7 & 16 & 11 & 25 & 3 & 7 \\
\hline Poor education systems among schools & 2 & 5 & 10 & 23 & 12 & 27 & 17 & 39 & 3 & 7 \\
\hline Hatred/discrimination by other community members in schools & 11 & 25 & 5 & 11 & 10 & 23 & 12 & 27 & 6 & 14 \\
\hline There is lack of morale by the few available teachers & 17 & 39 & 12 & 27 & 5 & 11 & 8 & 18 & 2 & 5 \\
\hline Lack of special equipment for teaching children with special needs & 12 & 27 & 13 & 29 & 10 & 23 & - & - & 9 & 20 \\
\hline Poor government policies affect such schools & - & - & 10 & 23 & 12 & 27 & 13 & 39 & 9 & 20 \\
\hline $\begin{array}{l}\text { There is not enough information concerning special needs } \\
\text { education. }\end{array}$ & 19 & 43 & 17 & 39 & 7 & 16 & - & - & 1 & 2 \\
\hline
\end{tabular}

Source: primary data (Own analysis)

As to whether shortage of staff in schools contributes to drop out of children with disabilities, $10(23 \%)$ strongly agreed, 20 (45\%) agreed, whereas 10 (23\%) disagreed and $4(9 \%)$ were not sure. This implies that respondents' views were in support that shortage of staff contributes to child dropouts from schools since the children will not have who to teach them.

The poor teachers liking (attitudes) towards the disabled children causes children to dropout, the respondents reacted as follows; 8 (18\%) strongly agreed, $15(34 \%)$ agreed, $11(25 \%)$ strongly disagreed, while 7 $(16 \%)$ disagreed, whereas $3(7 \%)$ were not sure. This is an indication that poor teacher attitudes towards the disabled children may or may not lead to drop out of children from rural schools, however, this reduces their morale to study and thus may lead to their drop outs.

The question to whether poor education systems contribute to the drop out of children from rural schools, the results indicated as follows; only $2(5 \%)$ were in strong agreement, $10(23 \%)$ agreed, while another 17 (39\%) were in strong disagreement and $12(27 \%)$ disagreed while $3(7 \%)$ were not sure that such systems force children to drop out of schools. Such results imply that the systems cannot be effective in communication and therefore may not help children to learn and understand what is being taught, leading to dropping out of children from rural schools.

To whether there is hatred and discrimination against the disabled children, $11(25 \%)$ of the respondents strongly agreed that discrimination against the disabled children forces them to drop out of rural schools, 5 (11\%) agreed while $12(27 \%)$ strongly disagreed. More 10 $(23 \%)$ of the respondents disagreed as well as $6(14 \%)$ who well not sure. This implies that when the society at large has a negative attitude towards the disabled, they feel hated and uncomfortable among other children, which contributes to their drop out from schools. However, the society attitudes towards the disabled children in schools should be improved.
The lack of morale by teachers as to whether leads to dropping out of children with disabilities from schools, the respondents reacted as follows; 17 (39\%) of the total respondents reported that they strongly agreed with such statement, $12(27 \%)$ agreed while $8(18 \%)$ strongly disagreed and $5(11 \%)$ disagreed, whereas only $2(5 \%)$ were not sure. This represents a trend where poor morale of teachers' means they will not teach and thus children also lose morale to study thus dropping out of schools.

Regarding the lack of special equipment for teaching children with special needs, $12(27 \%)$ of the total respondents strongly agreed, 13 (29\%) agreed, and 10 $(23 \%)$ disagreed, while $9(20 \%)$ were not sure. Such results indicate that when there is no equipment to teach the disabled children, it contributes to their dropping out from schools.

On whether poor government policies also contribute to child dropouts from schools, respondents reacted as follows; $10(23 \%)$ respondents agreed, $13(29 \%)$ strongly disagreed while $12(27 \%)$ disagreed and $9(20 \%)$ were not sure. This implies that there are certain policies which don't favor the education of the disabled children; however, such policies should be implemented to suit such children.

As regards to the presence of information, 19 (43\%) of the total respondents strongly agreed, 17 (39\%) reported that they agreed, $7(16 \%)$ disagreed while $1(2 \%)$ were not sure. This represents the people's ignorance about the disabled children's needs.

\section{Discussion}

Findings (table 1), indicated that $62 \%$ of respondents were in agreement that social and economic needs within children with disabilities were the major factor which contributes to drop out of children with disabilities from rural schools. This response is an indication that social and economic needs could lead to the dropping out of 
children with disabilities from rural schools because they also have the same needs as the able-bodied ones and are supported by Winzer [31] who emphasizes that disabled children drop out of schools because of unmet socio-economic and cultural needs.

The shortage of staff in schools contributing to drop out of children with disabilities, it was discovered that $68 \%$ of the respondents agreed. This implies that respondents' views were in support that shortage of staff contributes to child dropouts from schools since the children will not definately be affected among others. To make matters worse, there could be shaortage of special needs teachers. Such findings agree with both Lander et al.2001 who identify that lack of skilled teachers leads to child drop out.

The study discovered that poor teachers attitudes towards the disabled children cause children dropouts with average $52 \%$ of respondents agreeing. This is an indication that poor teacher attitudes towards the disabled children may or may not lead to drop out of children from rural schools; however, this reduces their morale to study and thus may lead to their dropouts. This is supported by Winzer [31] who observes that teachers attitudes towards learners with disabilities are demotivational, undermine their integration into mainstream classrooms and eventually drop out.

Poor education systems were found to contribute to the drop out of children from rural schools, where $73 \%$ were in disagreement. Poor government policies also contribute to child drop outs from schools, majority respondents $86 \%$. The presence of information, $82 \%$ of the total respondents, agreed. According to Oliver [26], the education system has failed to provide facilities to meet the needs of the disabled children; hence the dropouts and government policies with the absence of information all lead to child drop out.

The issues of hatred and discrimination against the disabled children, $64 \%$ of respondents disagreed. This implies that when the society at large has a negative attitude towards the disabled, they feel hated and uncomfortable among other children, which contributes to their drop out from schools. However, the society attitudes towards the disabled children in schools should be improved. Such results are in agreement with Ainscow [4], Ainscow, Farrell, and Tweddle [2], Ainscow, Booth, and Dyson [3]) that teachers prefer to direct their attention to the needs of the majority and the minority disabled also take the advantage to drop out from schools.

Regarding the lack of morale by teachers leads to dropping out of children with disabilities from schools, $66 \%$ of respondents agreed with such statement. This represents a trend where poor morale of teachers' means they will not teach and thus children also loose morale to study thus dropping out of schools. According to Warnock [32], teachers' inadequate preparation to handle such children leads to their dropping out from some schools.
Lack of special equipment for teaching children with special needs was also averagely supported $56 \%$ of the total respondents in agreement. Such results indicate that when there is no equipment to teach the disabled children, it contributes to their dropping out of schools. Hegarty, \& Just [14], Hegarty, \& Rao [15]) observes that equipment for learners with disabilities is costly for most schools to afford. Their absence, therefore, leads to dropouts.

\section{Conclusion and Recommendations}

The research investigated the factors contributing to the dropout of children with disabilities (CWDs) in rural schools in Ntungamo District, Uganda.

Majorly, lack of ;

- $\quad$ special equipment for teaching children with special needs, also for children to access school

- $\quad$ social and economic needs of CWD

- $\quad$ shortage of staff in schools and especially those with special needs education or related background.

- lack of morale by teachers and descrimination against CWD.

were reportedly existent and contributed to school dropout of CWD.

Government policies were found to be at fault, giving access to education to all children but did not consider for other factors such special needs.

These issues should not only be handled by Ministry of Education through management and staff in schools so that disabled children get equipment and materials to support their learning process but also the Government of Uganda and responsible ministry put aspects of inclusion of all children into consideration, and also provide the necessary financial support as well as intensifying long life learning programs for special needs teachers with focus on primary education to be able to deal with special needs children/CWDs.

The study proposes further extensive research on factors contributing CWD school dropout in Uganda among other developing world. Such study with a bigger sample size and also including the nature of disabilty of the children could easly be used for generalization.

\section{Acknowledgements}

We would like to thank the three anonymous reviewers; their comments have been so vital in the final revision of this paper. The study is highly indebted for their effort, and comments.

\section{REFERENCES}

[1] Abberley P. The Concept of Oppression and the 
Development of a Social Theory of Disability. Disability, Handicap \& Society. 1987;2(1):5-19.

[2] Ainscow, M., Farrell, P., \& Tweddle, D. Developing policies for inclusive education: a study of the role of local education authorities. International journal of inclusive education. 2000;4(3), 211-229.

[3] Ainscow, M., Booth, T., \& Dyson, A. (2006). Improving schools, developing inclusion. Routledge.

[4] Ainscow, M. (2007). Taking an inclusive turn. Journal of Research in Special Educational Needs, 7(1), 3-7.

[5] Aguti, J. N. (2002). Facing up to the challenge of Universal Primary Education (UPE) in Uganda through distance teacher education programmes. In Second Pan-Commonwealth Forum on Open Learning: Theme: Open Leaarning: Transforming Education for Development, Durban, South Africa. Retrieved May (Vol. 2, p. 2008).

[6] Allinder, R. M. (1994). The relationship between efficacy and the instructional practices of special education teachers and consultants. Teacher Education and Special Education, 17(2), 86-95.

[7] Avramidis, E., \& Norwich, B. (2002). Teachers' attitudes towards integration/inclusion: a review of the literature. European journal of special needs education, 17(2), 129-147.

[8] Creswell, J. W. (2009). Research Design: Qualitative, Quantitative, and Mixed Methods Approaches (3rd Ed.). Thousand Oaks, CA: Sage

[9] Creswell, J. W. (2011). Educational Research: Planning, Conducting and Evaluating Quantitative and Qualitative Research (4th Ed.). Upper Saddle River, NJ: Pearson Education.

[10] Deininger, K. (2003). Does cost of schooling affect enrollment by the poor? Universal primary education in Uganda. Economics of Education review, 22(3), 291-305.

[11] Fine, M., \& Asch, A. (1988). Disability beyond stigma: Social interaction, discrimination, and activism. Journal of social issues, 44(1), 3-21.

[12] Grogan, L. (2008). Universal primary education and school entry in Uganda. Journal of African Economies, 18(2), $183-211$.

[13] Hall, S. (1996). New ethnicities. Stuart Hall: Critical dialogues in cultural studies, 441-449.

[14] Hegarty, M., \& Just, M. A. (1993). Constructing mental models of machines from text and diagrams. Journal of memory and language, 32(6), 717-742.

[15] Hegarty, J. L., \& Rao, V. M. (1993). Amyloidoma of the nasopharynx: CT and MR findings. American journal of neuroradiology, 14(1), 215-218.

[16] Ishumi, A. G. (1994). Thirty years of learning: educational development in Eastern and Southern Africa from independence to 1990. IDRC, Ottawa, ON, CA.

[17] Jackson, H. (1993). Challenging Disability. A guide for frontline social workers in Africa. Harare: School of Soc. Work, \& Geneva: ILO.
[18] Jackson, J. B., Musoke, P., Fleming, T., Guay, L. A., Bagenda, D., Allen, M., ... \& Ducar, C. (2003). Intrapartum and neonatal single-dose nevirapine compared with zidovudine for prevention of mother-to-child transmission of HIV-1 in Kampala, Uganda: 18-month follow-up of the HIVNET 012 randomised trial. The Lancet, 362(9387), 859-868.

[19] Punch, K., F. (2005). Introduction to Social Research Quantitative and Qualitative Approaches. London: Sage. ISBN 0761944168 / ISBN 0761944176.

[20] Punch, K., F. (2009). Introduction to Research Methods in Education. Sage Publications Ltd ISBN-13: 978-1847870186.

[21] Koul, O. (1984). Azadirachtin, pt. 2. Interaction with the reproductive behaviour of red cotton bugs. Zeitschrift fuer Angewandte Entomologie.

[22] Lander, E. S., Linton, L. M., Birren, B., Nusbaum, C., Zody, M. C., Baldwin, J., ... \& Funke, R. (2001). Initial sequencing and analysis of the human genome.

[23] Maxwell, J. 2005. Qualitative Research Design: An interactive Approach (2nd ed). Thousand Oaks, CA: Sage

[24] Mudra, H., Klauss, V., Blasini, R., Kroetz, M., Rieber, J., Regar, E., \& Theisen, K. (1994). Ultrasound guidance of Palmaz-Schatz intracoronary stenting with a combined intravascular ultrasound balloon catheter. Circulation, 90(3), 1252-1261.

[25] Nishimura, M., Yamano, T., \& Sasaoka, Y. (2008). Impacts of the universal primary education policy on educational attainment and private costs in rural Uganda. international Journal of Educational development, 28(2), 161-175.

[26] Oliver, M. (1996). Understanding disability: From theory to practice. St Martin's Press.

[27] Oliver, M. (1996). A sociology of disability or a disablist sociology. Disability and society: Emerging issues and insights, 18-42.

[28] Seidman, A. W., \& Grier, B. C. (1992). Twenty-first-century Africa: towards a new vision of self-sustainable development. Africa World Pr.

[29] Seidman, A., \& Anang, F. (1992). 21st century Africa. Africa World.

[30] Susman, J. (1994). Disability, stigma and deviance. Social science \& medicine, 38(1), 15-22.

[31] Winzer, H. (1994). Die innerorganisatorische Diffusion neuer Bürokommunikationstechnologien. Eine evolutionäre Betrachtungsweise. Frankfurt aM.

[32] Warnock, H. M. (1978). Special educational needs: Report of the committee of enquiry into the education of handicapped children and young people. London: HM Stationery Office.

[33] World Health Organization 2011. World report on disability. Geneva, Switzerland. ISBN 9789240685215

[34] Hoogeveen, J.G., 2005. Measuring welfare for small but vulnerable groups: Poverty and disability in Uganda. Journal of African economies, 14(4), pp.603-631. 
[35] Lwanga-Ntale, C., 2003. Chronic poverty and disability in Uganda.

[36] Katsui, H. and Kumpuvuori, J., 2008. Human rights based approach to disability in development in Uganda: A way to fill the gap between political and social spaces? Scandinavian Journal of Disability Research, 10(4), pp.227-236.

[37] Barrett, H. and Marshall, J., 2013. Implementation of the World Report on Disability: Developing human resource capacity to meet the needs of people with communication disability in Uganda. International journal of speech-language pathology, 15(1), pp.48-52.

[38] Labie, M., Méon, P.G., Mersland, R. and Szafarz, A., 2015. Discrimination by microcredit officers: Theory and evidence on disability in Uganda. The Quarterly Review of Economics and Finance, 58, pp.44-55. 